\title{
Hemato-Biochemical Alterations in Water Buffaloes Clinically Infected with Bovine Theileriosis Before and After Treatment by Buparvaquone
}

\author{
Ahmed N F NEAMAT-ALLAH \\ Department of Clinical Pathology, Faculty of Veterinary Medicine, Zagazig University, 1 Alzeraa Street \\ Postal Code 44511, Zagazig City, Sharkia Province, Egypt \\ *Corresponding author:drnemovete@yahoo.com,a_neamatallah@yahoo.com
}

Bulletin UASVM Veterinary Medicine 73(1) / 2016,

Print ISSN 1843-5270; Electronic ISSN 1843-5378

DOI:10.15835/buasvmcn-vm: 11671

\begin{abstract}
Most of researches about theileriosis have been done about its effect in cows and derelict it in water buffaloes. So this investigation is aimed to study the hematological and serum constituents alterations in buffaloes affected with bovine theileriosis in Egypt. A total of thirty six buffaloes about 3-5 years old were examined in this study. Twenty six were naturally infected by theileria. Another ten buffaloes of the same age and apparent healthy were kept as control. The infected buffaloes were treated by buparvaquone (50 mg/20 kg B.W). Blood were taken from the healthy, infected non treated buffaloes and then post one and two weeks from buparvaquone administration. The affected buffaloes revealed high fever, corneal opacity, lacrimation, enlargement of the prescapular lymph node. Blood smears confirm presence of piroplasms of T. annulata in red blood corpuscles. Hematological analysis showed a significant reduction in erythrocytes count (RBCs), packed cell volume (PCV) and hemoglobin concentration (Hb) in non treated buffaloes infected by theileria. Normocytic normochromic anemia was reported rapidly with the first appearance of signs. Latterly, macrocytic hypochromic anemia .Total leucocyte count significantly increased soon after infection and persists until the first week post buparvaquone treatment. Theileria infected non treated buffaloes revealed an increase in the serum activities of aminotransferase (AST and ALT). Also serum levels of total bilirubin, unconjugated bilirubin (UB), conjugated bilirubin (CB), creatinine and blood urea nitrogen level were increased. In the opposite, side, the total serum proteins and albumin levels significantly decreased. Significant increase in malonyldialdehyde (MDA) activity was recorded with a significant decease in the catalase activity (CAT) in T. annulata clinically infected buffaloes. These alterations were improved by treatment of the diseased buffaloes by buparvaquone two weeks post administration.
\end{abstract}

Keywords: biochemistry, buffaloes, Buparvaquone, hematology, theileriosis

\section{INTRODUCTION}

Blood parasites represent a major health problem in cattle breeding due to severe economic losses. That, lead to a decrease of animal production and an increase both of susceptibility to other infections and mortalities (Miodrag et al., 2012). Theileriosis is transmitted by vector ticks of the genus Hyalomma, so it is one of a tick borne disease of cattle (Glass et al., 2003). It is called tropical theileriosis or Mediterranean or even Egyptian fever. It is caused by Theileria annulata (T. annulata). It spread from the Mediterranean and Middle East area, from Morocco to Western parts of India and China (Razmi et al., 2003). T. annulata is one of the most destructive blood parasite affecting cattle, buffaloes, and even sheep.

Early diagnosis of T. annulata infection in bovines is mostly based on clinical signs as well as the detection of piroplasms in red blood corpuscles in Giemsa stained blood smears (Kaufmann, 1996) . Early therapeutic approach can prevent the high mortality rates (Modi and Bhadesiya, 2014) .

Basic control of tropical theileriosis depends on acaricides and chemotherapy (Tait and Hall, 
1990). Buparvaquone is currently the most specific used chemotherapeutic treatment against theileriosis from 1980 till now (Müller etal., 2015).

Many studies have been done about theileriosis in cows and derelict its effect in water buffaloes, so the present study is to estimate the effects of bovine theileriosis in buffaloes and the efficacy of buparvaquone as anti theilerial drug. The evaluation will be done by hematological, biochemical and antioxidant examination.

\section{MATERIALS AND METHODS}

Animal

The present study was carried out on twenty six clinically diseased buffaloes showed clinical symptoms of theileriosis and confirmed by detection of intraerythrocytic stages of the hemoparasite and another ten clinically have been used as apparent healthy buffaloes.

Treatment of infected animals:

The diseased buffaloes were treated with BUTAJECT, (Adwia Pharmaceuticals, Egypt $50 \mathrm{mg}$ buparvaquone $/ \mathrm{ml}$ ) by recommended dose 50 $\mathrm{mg} / 20 \mathrm{~kg}$ body weight by intramuscular in the neck region.

\section{Blood film:}

Thin blood smears from the ear vein of diseased buffaloes. The smears were dried off then fixed by methyl alcohol and stained with commercial Giemsa stain (Coles, 1986). They have been be examined under oil immersion lens of microscope at (100X) according to ( Kaufmann, 1996). Examination of blood smear for theileria was done by cross-section method to give representative examination according to (Ali and Radwan, 2011).

\section{Samples:}

Blood sample was collected from jugular vein of each buffalo and divided into two portions. The first portion of the blood was collected in EDTA tubes for hematological parameters. The second was collected without anticoagulant for serum separation for biochemical parameters analysis. Samples were taken from the healthy, infected non treated buffaloes and then post one and two weeks from buparvaquone administration.

\section{Hematological studies:}

Blood samples for hematological examination were sent to laboratory within two hours for determination of (RBCs, Hb, PCV, MCV, MCHC, MCH and WBCs) using full automatic digital cell counter (Hospitex Hemascreen 18, Italy).

\section{Serum biochemical studies:}

The serum was separated by centrifugation at $3000 \mathrm{rpm}$ for $25 \mathrm{~min}$ and stored at $-20^{\circ} \mathrm{C}$ until used, then have been tested spectrophotometrically for the biochemical parameters. Total proteins ,albumin and globulins were measured (Doumas et al., 1981; Drupt, 1974; Coles, 1986) respectively. Activities of serum aminotransferases (ALT and AST) were determined (Reitman and Frankel, 1957), while serum creatinine and blood urea nitrogen levels were estimated ; $\{$ Putton, 1977, Determination of serum blood urea nitrogen\} Putton and Crouch, 1977). Serum reduced GSH was determined according to the method of Beutler et al. (1963). While, malonyldialdehyde (MAD) was determined according to the method of Ohkawa et al. (1979). Catalase (CAT) was determined by the method of Aebi (1984).

\section{Statistical analysis:}

By using SPSS version 8 for windows, the obtained data were statistically analyzed. One way analysis of variance (ANOVA) have been applied (Tamhane and Dunlop, 2000). Means at the same rows followed by distinct letters were significantly distinct. The letter (a) was representing the highest value.

\section{RESULTS AND DISCUSSION}

Mediterranean coast fever or tropical theileriosis caused by T. annulata. It is one of the most important diseases of cattle in Egypt, which lead to severe economic losses among them (Abou-El-Naga et al., 2005).The most obvious clinical symptoms on theileria infected buffaloes were fever $\left(>40^{\circ} \mathrm{c}\right)$, anorexia, enlargement of lymph nodes, corneal opacity and lacrimation (Fig. 1 and 2). These clinical signs are similar to those reported in theileria infected cows (AL-Hosary et al., 2015). Blood smears revealed presence of theileria trophozyte (Fig. 3) in side erythrocytes in the present study.

Results of erythrogram (Tab. 1) revealed that theileria infected non treated buffaloes showed a significant decrease in erythrocytes count, packed cell volume and hemoglobin when compared with the healthy control. This reduction may probably because of severe damage caused by the organisms inside the erythrocyte during their multiplication (Ganguly et al., 2015).The 
obtained data of the mean corpuscular volume (MCV) and the mean corpuscular hemoglobin concentration (MCHC) were classified the produced anemia as a normocytic normochromic in infected non treated buffaloes. Macrocytic hypochromic anemia was pronounced in the buparvaquone treated buffaloes one and two weeks post buparvaquone administration. This picture may be a signs of regenerative anemia (Coles, 1986). Mean corpuscular hemoglobin $(\mathrm{MCH})$ revealed a significant increase in the theileria infected non treated buffaloes compared with the healthy control that confirm hemolytic condition (Feldman et al., 2000). The erythrogram returned toward the normal values two weeks post buparvaquone administration. This indicated that the treated buffaloes start the resumption to their normal status. The recuperation could be due to the helps of buparvaquone in elimination of both piroplasmic and lymphocytic stages of the protozoan parasites from both blood and lymph nodes (AL-Hosary et al., 2015) .

Leucogram (Tab. 2) revealed leukocytosis in the theileria infected non treated buffaloes which is entirely due to lymphocytes proliferation in the lymphoid organs and granulocyte as a defensive response to invading protozoans (Modi et al., 2015). Also the lymphocytosis may be due to that the intra-lymphocytic theilerial parasites stimulate the host cells, leading to growth of lymphocytes (Yamaguchi et al., 2010). The same results were obtained by (Stockham et al., 2000).



Fig. 1. Water buffalo showing enlargement of prescapular lymph node

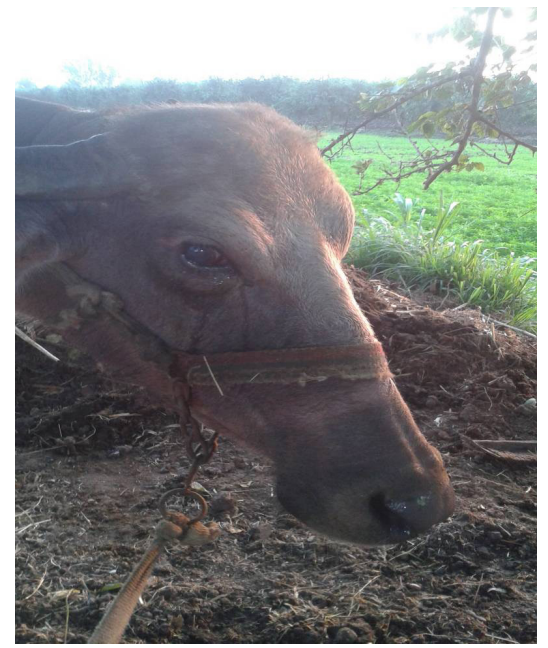

Fig. 2. Water buffalo showing corneal opacity and watery lacrimation

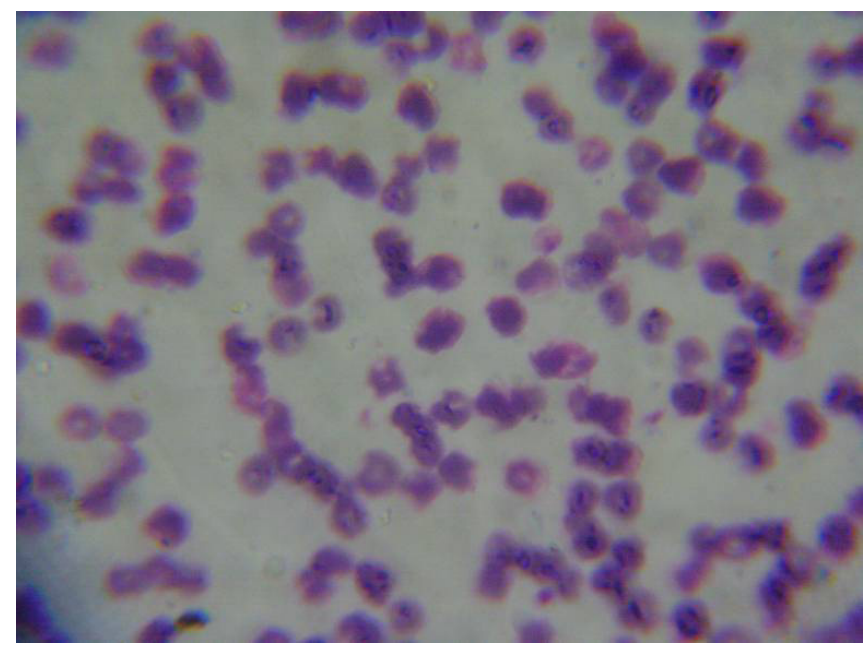

Fig. 3. Showing intra erythrocytic trophozyte of Theileria annulata. 
On the contrary, (Omer et al., 2002) who reported a pan leucopenia in pure bred cattle infected with theileriosis in Saudi Arabia. Similar findings were obtained by (Ghanem et al., 2013) who reported that Egyptian water buffaloes clinically diagnosed as theileriosis showed a reduction in the total leucocyte counts. This variance in the leucogram may be due to the different infection stages in the different investigations, since within an acute phase of infection; there is a wave of leucocytic response, which gradually drop as the infection becomes chronic.

Disturbances in the liver and kidneys functions (Tab. 3 and 4) demonstrated a significant increase in the serum activities of aminotransferases (AST and ALT) in the theileria infected non treated buffaloes.

Tab. 1. Erythrogram in the normal buffaloes and clinically infected with T. annulata (mean values \pm SE).

\begin{tabular}{|c|c|c|c|c|c|}
\hline \multirow[b]{3}{*}{ Parameters } & \multicolumn{5}{|c|}{ Groups } \\
\hline & \multirow[b]{2}{*}{$\begin{array}{l}\text { Healthy buf- } \\
\text { faloes }\end{array}$} & \multicolumn{3}{|c|}{ Theileria infected buffaloes } & \multirow[b]{2}{*}{ F test } \\
\hline & & Non treated & $\begin{array}{l}1 \text { week post bu- } \\
\text { parvaquone } \\
\text { administration }\end{array}$ & $\begin{array}{l}2 \text { week post bu- } \\
\text { parvaquone } \\
\text { Administration }\end{array}$ & \\
\hline \multirow{2}{*}{$\begin{array}{c}\text { RBCs } \\
\left(\mathrm{x} 10^{6} / \mu \mathrm{l}\right) \\
\mathrm{PCV} \\
\% \\
\mathrm{Hb}\end{array}$} & $8.15^{\mathrm{a}} \pm 0.11$ & $6.44^{\mathrm{c}} \pm 0.05$ & $7.71^{\mathrm{b}} \pm 0.26$ & $8.23^{\mathrm{a}} \pm 0.05$ & $* *$ \\
\hline & $40.04^{\mathrm{a}} \pm 0.49$ & $32.04 \mathrm{c} \pm 0.30$ & $38.86^{b} \pm 0.41$ & $42.3^{\mathrm{a}} \pm 0.48$ & $* *$ \\
\hline \multirow{2}{*}{$\mathrm{gm} / \mathrm{dl}$} & $13.56^{\mathrm{a}} \pm 0.02$ & $11.76^{c} \pm 0.10$ & $13.20^{\mathrm{b}} \pm 0.40$ & $13.54^{\mathrm{a}} \pm 0.03$ & ** \\
\hline & $49.12^{\mathrm{a}} \pm 0.19$ & $49.75^{\mathrm{a}} \pm 0.16$ & $50.40^{\mathrm{b}} \pm 10.40$ & $51.39^{b} \pm 0.13$ & $* *$ \\
\hline \multirow{2}{*}{$\begin{array}{c}\mathrm{MCHC} \\
\% \\
\mathrm{MCH}\end{array}$} & $33.92^{\mathrm{a}} \pm 0.45$ & $33.87^{\mathrm{a}} \pm 0.34$ & $33.68^{\mathrm{a}} \pm 0.44$ & $31.90^{\mathrm{b}} \pm 0.70$ & $*$ \\
\hline & $16.66^{\mathrm{b}} \pm 0.24$ & $18.24^{\mathrm{a}} \pm 0.24$ & $17.12^{\mathrm{ab}} \pm 0.08$ & $16.46^{b} \pm 0.19$ & ** \\
\hline $\begin{array}{l}\text { Means at the same ro } \\
* * \text { *Highly significant a } \\
* \text { significant at } \mathrm{P} \leq 0.0 \\
\text { RBC }=\text { red blood corp } \\
\text { Hb = hemoglobin } \\
\text { PCV = packed cell vol } \\
\text { MCH = mean corpus } \\
\text { MCV = mean corpust } \\
\text { MCHC = mean corpus }\end{array}$ & $\begin{array}{l}\text { lowed by distinct } 1 \\
.01 \\
\text { es } \\
\text { hemoglobin } \\
\text { volume } \\
\text { r hemoglobin conce }\end{array}$ & ters were significa & istinct and the letter & representing to the hig & st value. \\
\hline
\end{tabular}

Tab. 2. Leucogram in the normal buffaloes and clinically infected with T. annulata (mean values $\pm \mathrm{SE})$.

\begin{tabular}{|c|c|c|c|c|c|}
\hline \multirow[b]{3}{*}{ Parameters } & \multicolumn{5}{|c|}{ Groups } \\
\hline & \multirow[b]{2}{*}{$\begin{array}{l}\text { Healthy } \\
\text { buffaloes }\end{array}$} & \multicolumn{3}{|c|}{ Theileria infected buffaloes } & \multirow[b]{2}{*}{ F test } \\
\hline & & Non treated & $\begin{array}{c}1 \text { week post } \\
\text { buparvaquone } \\
\text { administration }\end{array}$ & $\begin{array}{l}2 \text { week post } \\
\text { buparvaquone } \\
\text { administration }\end{array}$ & \\
\hline $\mathrm{WBC}\left(\times 10^{3} / \mu \mathrm{l}\right)$ & $8.44^{c} \pm 0.05$ & $10.02^{\mathrm{a}} \pm 0.18$ & $9.00^{\mathrm{b}} \pm 0.24$ & $8.45^{c} \pm 0.06$ & $* *$ \\
\hline $\operatorname{LYM}\left(\times 10^{3} / \mu \mathrm{l}\right)$ & $5.00^{\mathrm{b}} \pm 0.16$ & $5.66^{\mathrm{a}} \pm 0.20$ & $4.91^{c} \pm 0.01$ & $5.21^{\mathrm{b}} \pm 0.17$ & $* *$ \\
\hline $\operatorname{MID}\left(\times 10^{3} / \mu \mathrm{l}\right)$ & $1.94^{\mathrm{a}} \pm 0.02$ & $1.04^{\mathrm{b}} \pm 0.03$ & $1.66^{\mathrm{a}} \pm 0.21$ & $1.92^{\mathrm{a}} \pm 0.03$ & $*$ \\
\hline GRA $\left(\times 10^{3} / \mu\right)$ & $1.50^{c} \pm 0.13$ & $3.30^{\mathrm{a}} \pm 0.11$ & $2.43^{\mathrm{b}} \pm 0.45$ & $1.31^{\mathrm{c}} \pm 0.12$ & $* *$ \\
\hline $\begin{array}{l}\text { Means at the same rov } \\
* * \text { Highly significant at } \\
* \text { Significant at } \mathrm{P} \leq 0.0 \\
\text { WBC }=\text { White blood ce } \\
\text { LYM = lymphocytes } \\
\text { GRA = neutrophils, eo } \\
\text { MID = monocytes and }\end{array}$ & $\begin{array}{l}\text { il's and basop } \\
\text { eosinophil's }\end{array}$ & etters were signific & distinct and the lett & as representing to th & hest value \\
\hline
\end{tabular}


Also, serum levels of total bilirubin, unconjugated bilirubin (UB), conjugated bilirubin (CB), creatinine and blood urea nitrogen level showed a significant increase. In contrary, total serum proteins and albumin levels showed significant decrease. These changes probably indicated an inflammatory changes in hepatic and glomerular cells that in turn affected their functions (Abou-El-Naga et al., 2005). These results are in agreement with Sandhu et al. (1998) who reported a hepatic and renal damages in liver and kidneys of calves infected Tannulata that appeared in macroscopic and microscopic evaluation. These results were returned to the normal level two weeks post buparvaquone administration compared to the apparent healthy values.

Antioxidants play complementary roles in many aspects of pathogenesis of T. annulata infection. The results presented in Tab. 5 revealed a significant increase in malonyldialdehyde (MDA) activity and a significant decease in catalase activity (CAT) in theileria infected non treated buffaloes compared with healthy one. Reduction of CAT activity may be attributed to the reduction of antioxidant enzymes as they are used by excessive free radicals in the infected buffaloes (Hassanpour et al., 2013). The data obtained in the present study, regarding MDA levels were correlated with

Tab. 3. Total proteins, albumin and globulin levels in the normal buffaloes and clinically infected with $T$. annulata (mean values $\pm \mathrm{SE}$ ).

\begin{tabular}{|c|c|c|c|c|c|}
\hline \multirow[b]{3}{*}{ Parameters } & \multicolumn{5}{|c|}{ Groups } \\
\hline & \multirow[b]{2}{*}{$\begin{array}{l}\text { Healthy } \\
\text { buffaloes }\end{array}$} & \multicolumn{3}{|c|}{ Theileria infected buffaloes } & \multirow[b]{2}{*}{$\begin{array}{c}\mathrm{F} \\
\text { test }\end{array}$} \\
\hline & & Non treated & $\begin{array}{c}1 \text { week post } \\
\text { buparvaquone } \\
\text { administration }\end{array}$ & $\begin{array}{c}2 \text { week post } \\
\text { buparvaquone } \\
\text { administration }\end{array}$ & \\
\hline $\begin{array}{l}\text { Total proteins } \\
(\mathrm{g} / \mathrm{dl})\end{array}$ & $7.02^{\mathrm{a}} \pm 0.05$ & $6.07^{c} \pm 0.13$ & $6.39^{c} \pm 0.11$ & $7.25^{\mathrm{a}} \pm 0.09$ & $* *$ \\
\hline Albumin (g/dl) & $3.80^{\mathrm{a}} \pm 0.10$ & $2.97^{\mathrm{c}} \pm 0.03$ & $3.18^{\mathrm{b}} \pm 0.10$ & $3.83^{\mathrm{a}} \pm 0.03$ & $* *$ \\
\hline Globulin (g/dl) & $3.22^{\mathrm{a}} \pm 0.08$ & $3.10^{\mathrm{a}} \pm 0.09$ & $3.21^{\mathrm{a}} \pm 0.05$ & $3.42^{\mathrm{a}} \pm 0.05$ & N.S \\
\hline $\begin{array}{l}\text { Means at the same rov } \\
\text { value. } \\
\text { **Highly significant at } \\
\text { N.S = non significant }\end{array}$ & $\begin{array}{l}\text { ollowed by disti } \\
\leq 0.01\end{array}$ & Tetters were sign & & & \\
\hline
\end{tabular}

Tab. 4. Some biochemical parameters in the normal buffaloes and clinically infected with T.annulata (mean values $\pm \mathrm{SE}$ ).

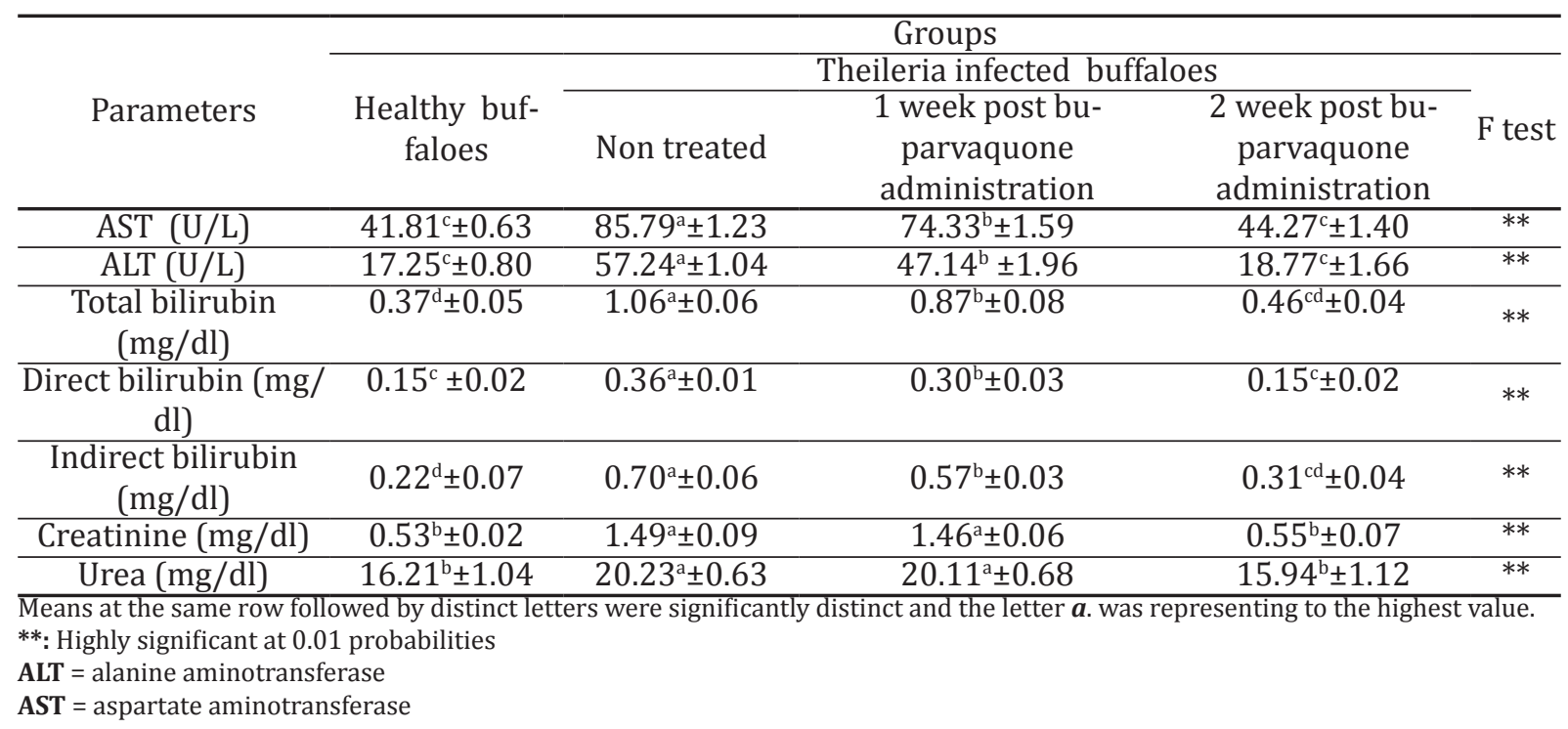


Tab. 5. Catalase and malonyldialdehyde levels in the normal buffaloes and clinically infected with $T$. annulata (mean values $\pm \mathrm{SE}$ ).

\begin{tabular}{|c|c|c|c|c|c|}
\hline \multirow[b]{3}{*}{ Parameters } & \multicolumn{5}{|c|}{ Groups } \\
\hline & \multirow[b]{2}{*}{$\begin{array}{l}\text { Healthy } \\
\text { buffaloes }\end{array}$} & \multicolumn{3}{|c|}{ Theileria infected buffaloes } & \multirow[b]{2}{*}{ F test } \\
\hline & & Non treated & $\begin{array}{c}1 \text { week post } \\
\text { buparvaquone } \\
\text { administration }\end{array}$ & $\begin{array}{c}2 \text { week post } \\
\text { buparvaquone } \\
\text { administration }\end{array}$ & \\
\hline $\begin{array}{c}\text { Catalase } \\
(\mathrm{U} / \mathrm{L})\end{array}$ & $2.61^{\mathrm{a}} \pm 0.07$ & $1.49^{\mathrm{c}} \pm 0.11$ & $1.79^{\mathrm{b}} \pm 0.07$ & $2.56^{\mathrm{a}} \pm 0.05$ & $* *$ \\
\hline $\begin{array}{l}\text { Malonyldialdehyde } \\
\text { (nmol/ml) }\end{array}$ & $0.87^{c} \pm 0.06$ & $1.46^{\mathrm{a}} \pm 0.17$ & $1.29^{\mathrm{b}} \pm 0.12$ & $0.90^{c} \pm 0.03$ & $* *$ \\
\hline
\end{tabular}

those presented by Grewal et al. (2005). MDA level indicated that lipid peroxidation in erythrocytes of affected buffaloes was significantly higher than those of apparent healthy. After treatment by buparvaquone, these results were completely varied, the level of MDA has been significantly decreased and a significant increase in the activity of CAT has been recorded.

\section{CONCLUSION}

It could be concluded that T. annulata infected non treated buffaloes showed adverse alterations on the hematological profile, biochemical parameters of liver, kidneys and oxidative stress. These alterations were significantly improved two weeks after buparvaquone administration.

CONFLICT OF INTEREST: not exist.

Acknowledgments. The author would like to thank Dr. Amany Abdel Elghany. Lecturer of parasitology. Faculty of Veterinary Medicine at Zagazig University for his help in examining and reading blood film for detection of intracellular parasites.

\section{REFERENCES}

1. Abou-El-Naga T, Abdou T, Mahmoud M (2005). Clinicopathological Studies on Theileria annulata Infection in Siwa Oasis, Egypt. Beni-Suef Vet Med J 15:4046.

2. Aebi H (1984). Catalase in vitro. Methods Enzymol 105:121-126.

3. AL-Hosary A, EL-Sayed H, Ahmed L (2015). Oxidative stress and hematological profile in Theileria annulata clinically infected cattle before and after treatment. Assiut Vet Med J 6 (144):123-129.
4. Ali A, Radwan M (2011). Molecular Detection of Theileria Annulata in Egyptian Buffaloes and Biochemical Changes Associated with Particular Oxidative Changes. Advances in Life Sciences 1(1):6-10.

5. Beutler E, Duron O, Kelly MB (1963). Determination of blood glutathione. J Clin Med 882.

6. Coles E (1986). Veterinary clinical pathology. $2^{\text {nd }}$ ed, W.B. Saunders Company, Philadelphia and London.

7. Doumas B, Baysa D, Carter R, Peters T , Schaffer R (1981).Determination of serum total proteins. Clin Chem 27(10):1642.

8. Drupt F (1974).Colorimetric method for determination of serum albumin. Pharm Bio Sci 7:999.

9. Feldman B, Zinki J, Jain V (2000). Schalm's Veterinary Hematology. 5th ed, Lippincott Williams and Wilkins, Canada.

10. Ganguly A, Bhanot V, Bisla R, Ganguly I, Singh H, Chaudhri $S$ (2015). Hematobiochemical alterations and direct blood polymerase chain reaction detection of Theileria annulata in naturally infected crossbred cows. Veterinary World 8(1):24-28.

11. Ghanem MM, Abdelhamid OM, Bakir NM (2013). Clinicobiochemical, serological and molecular study on tropical theileriosis in Egyptian water buffaloes (Bubalus bubalis). Alex J Vet Sci 39(1):1-11.

12. Glass E, Craigmile S, Springbett A, Preston P, Kirvar E, Wilkie G, Eckersall P, Hall R, Brown C (2003). The protozoan parasite, Theileria annulata, induces a distinct acute phase protein response in cattle that is associated with pathology. Int J Parasitol 33(12):1409-1418.

13. Grewal A, Ahuja CS, Singha SP, Chaudhary KC (2005). Status of lipid peroxidation, some antioxidant enzymes and erythrocyte fragility of crossbred cattle naturally infected with Theileria annulata. Vet Res Commun 29(5):387-394.

14. Hassanpour A, Sabegh YG, Sadeghi-nasab A (2013). Assessment of serum antioxidant enzymes activity in cattle suffering from Theileriosis. European Journal of Experimental Biology 3(1):493-496.

15. Husdan H, Rapoport K (1968). Chemical determination of creatinine with deproteinization. Clin Chem 14:222-238. 
16. Kaufmann J (1996). Parasitic Infections of Domestic Animals : A Diagnostic Manual. Springer Basel AG, Basel, Boston, Berlin.

17. Laurell C (1966). Quantitative estimation of proteins by electrophoresis in agarose gel containing antibodies. Analytical Biochemistry 15:45-52.

18. Miodrag R, Ian M, James A (2012). Diseases of Cattle in the Tropics: Economic and Zoonotic Relevance (Current Topics in Veterinary Medicine). Springer, Softcover reprint of the original, Berlin.

19. Modi D, Bhadesiya C (2014). Tick-borne Theileria annulata infection in dairy cows: A short note for field vets. Int J Life Sci Res 2(4):127-129.

20. ModiD, Bhadesiya C,Mandali G(2015).Hematobiochemical Changes in Crossbred Cattle Infected with Theileria annulata in Banaskantha District of Gujarat. International Journal of Scientific and Research Publications 5(1):1-4.

21. Müller J, Aguado-Martinez A, Manser V, Balmer V, Winzer P, Ritler D, Hostettler I, Arranz-Solís D, Ortega-Mora L, Hemphill A (2015). Buparvaquone is active against Neospora caninum in vitro and in experimentally infected mice. Int J Parasitol Drugs Drug Resist 5(1): 16-25.

22. Ohkawa H, Ohishi N, Yagi k (1979). Assay For Lipid peroxides in animal tissues by thioborbituric acid reaction. Anal Biochem 95:351-358.

23. Omer OH, El-Malik KH, Mahmoud OM, Haroun EM, Hawas A, Sweeney D, Magzoub M (2002). Haematological profiles in pure bred cattle naturally infected with Theileria annulata in Saudi Arabia. Vet Parasitol 107(1-2):161-168.

24. Putton, C, Crouch S (1977). Determination of serum blood urea nitrogen. Anal Chem 49:464-469.
25. Razmi GR, Hosseini M, Aslani MR (2003). Identification of tick vectors of ovine theileriosis in an endemic region of Iran. Vet Parasitol 116(1):1-6.

26. Reitman S, Frankel S, (1957). A colorimetric method for determination of serum glutamicoxaloacetic transaminase and serum glutamic pyruvic transaminase.. Am J Clin Pathol 25:56.

27. Sandhu GS, Grewal AS, Singh A, Kondal JK, Singh J, Brar RS (1998). Haematological and biochemical studies on experimental Theileria annulata infection in crossbred calves. Vet. Res. Comm 22(5):347-354.

28. Stockham SL, Kjemtrup AM, Conrad PA, Schmidt DA, Scott MA, Robinson TW, Tyler, JW, Johnson GC, Carson C ,Cuddihee, P (2000). Theileriosis in a Missouri Beef herd caused by Theileria buffeli : Case Report, Herd Investigation, Ultrastructure, Phylogenetic Analysis, and Experimental Transmission. Vet Pathol 37(1):11-21.

29. Tait A, Hall FR (1990). Theileria annulata: control measures, diagnosis and the potential use of subunit vaccines. Rev Sci Tech 9(2):387-403.

30. Tamhane A, Dunlop D (2000). Statistic and Data Analysis from Elementary to Intermediate. Prentice Hall, Upper Saddle River, New Jersey.USA.

31. Yamaguchi T, Yamanaka M, Ikehara S, Kida K, Kuboki N, Mizuno D (2010). Generation of IFN-Y producing cells that recognize the major piroplasm surface protein in Theileria orientalis infected bovines. Vet Parasitol 171(34):207-215. 